\title{
Touristic development of the La Lopé National Park (Gabon) in light of the SWOT analysis
}

\section{Abstract}

The purpose of this article is to evaluate the possibilities of touristic development of the La Lopé National Park and to indicate the most important barriers and limitations of the area exploitation. For this purpose a SWOT method was applied. This assignment presents the situation as of the end of 2014. The majority of the up-to-date data was collected during the mission, the purpose of which was to observe the region, and which was organized by Université Omar Bongo in Libreville and Warsaw University. The La Lopé National Park has a significant touristic potential which is very poorly used. The diagnose of the reasons for that can be an indicator for attempts to rationally use the resources of the region and present an appropriate development strategy.

Keywords

La Lopé • national park • ecotourism • Gabon • nature protection

\author{
Maciej Jędrusik ${ }^{1}$, Andrzej Lisowski², \\ Dieudonné Mouketou-Tarazewicz ${ }^{3}$, \\ Marc-Louis Ropivia ${ }^{4}$, Bogdan Zagajewski \\ 'Department of World Regional \\ Geography, Faculty of Geography \\ and Regional Studies, \\ University of Warsaw, \\ Poland \\ e-mail: maciusik1@uw.edu.pl \\ 2Department of Urban Geography \\ and Spatial Management, Faculty of \\ Geography and Regional Studies, \\ University of Warsaw, Poland \\ e-mail: aslisows@uw.edu.pl \\ ${ }^{3}$ University Omar Bongo in Libreville, \\ Gabon, Department of Geoinformatics \\ and Remote Sensing, Faculty of \\ Geography and Regional Studies, \\ University of Warsaw, Poland \\ e-mail:diket22@hotmail.com \\ ${ }^{4}$ University Omar Bongo in Libreville, \\ Gabon \\ e-mail: mropivia@gmail.com \\ 5Department of Geoinformatics, \\ Cartography and Remote Sensing, \\ Faculty of Geography and Regional \\ Studies, University of Warsaw, Poland \\ e-mail: bogdan@uw.edu.pl \\ Received: 2 February 2015 \\ Accepted: 31 May 2015
}

Introduction

The La Lopé National Park is located in four counties (Ogooué-Ivindo, Ogouée-Lolo, Ngounié and Moyen-Ogouée) in central Gabon. It is one of the largest national parks of Gabon $4913 \mathrm{~km}^{2}$ (Plan de gestion... 2006, p.7) ${ }^{1}$. Geologically this is one of the oldest areas in the world. The oldest bedrocks (granodiorites) date back to 2 to 2.7 billion years. The region is slightly elevated (approx. 300-350 m above sea level) with the dominant peak of Mont Brazza (470 $\mathrm{m}$ above sea level), rising towards the south where it reaches more than $900 \mathrm{~m}$. In the northern part the La Lopé subsidence is lowering, through which the largest river of the park (and Gabon) flows for approximately $100 \mathrm{~km}$. The Ogooué River has a swift stream with an average drop of $10 \mathrm{~m} / \mathrm{km}$. It intensifies erosion, resulting in the appearance of river terraces.

Situated almost on the equator, but in the rain shadow of Chaillu and Monts de Cristal, the La Lopé park is relatively

${ }^{1}$ Sources provide different surface areas of the park. According to R. Ndémanou the surface area of the park is $4848.94 \mathrm{~km}^{2}$, and the neighboring zone (zone tampon) $1500 \mathrm{~km}^{2}$ sparsely trickled. The fact that it is one of the driest regions in the country does not guarantee an easy access to many places in the wet season. Average annual rainfall in Lopé between 1984 and 2004 slightly exceeded $1500 \mathrm{~mm}$ (Plan de gestion 2006, p.11). The dry season lasts three months. Average annual temperature with small annual amplitudes is $26^{\circ} \mathrm{C}$.

There are no residential estates in the park. Several estates were built in the peripheral zone or in its direct neighborhood. The largest of them are Lopé-Boléko (approx. 600 residents, surface area 621 ha) and Ayem (approx. 300 residents, surface area 71 ha). Others: Kazambabika, Makoghé, Mikongo, Aschouka, Badondé and Ramba have several dozen of residents each or they are completely depopulated, such as Kongomboumba. Total surface area taken by the residential estates is $26.88 \mathrm{~km}^{2}$ (Ndémanou). The area is depopulating quickly. In December 2014 a local tour guide estimated that the population of the residential estate in Lopé decreased from approx. 5000 in 2005 to 300-400 in 2014 

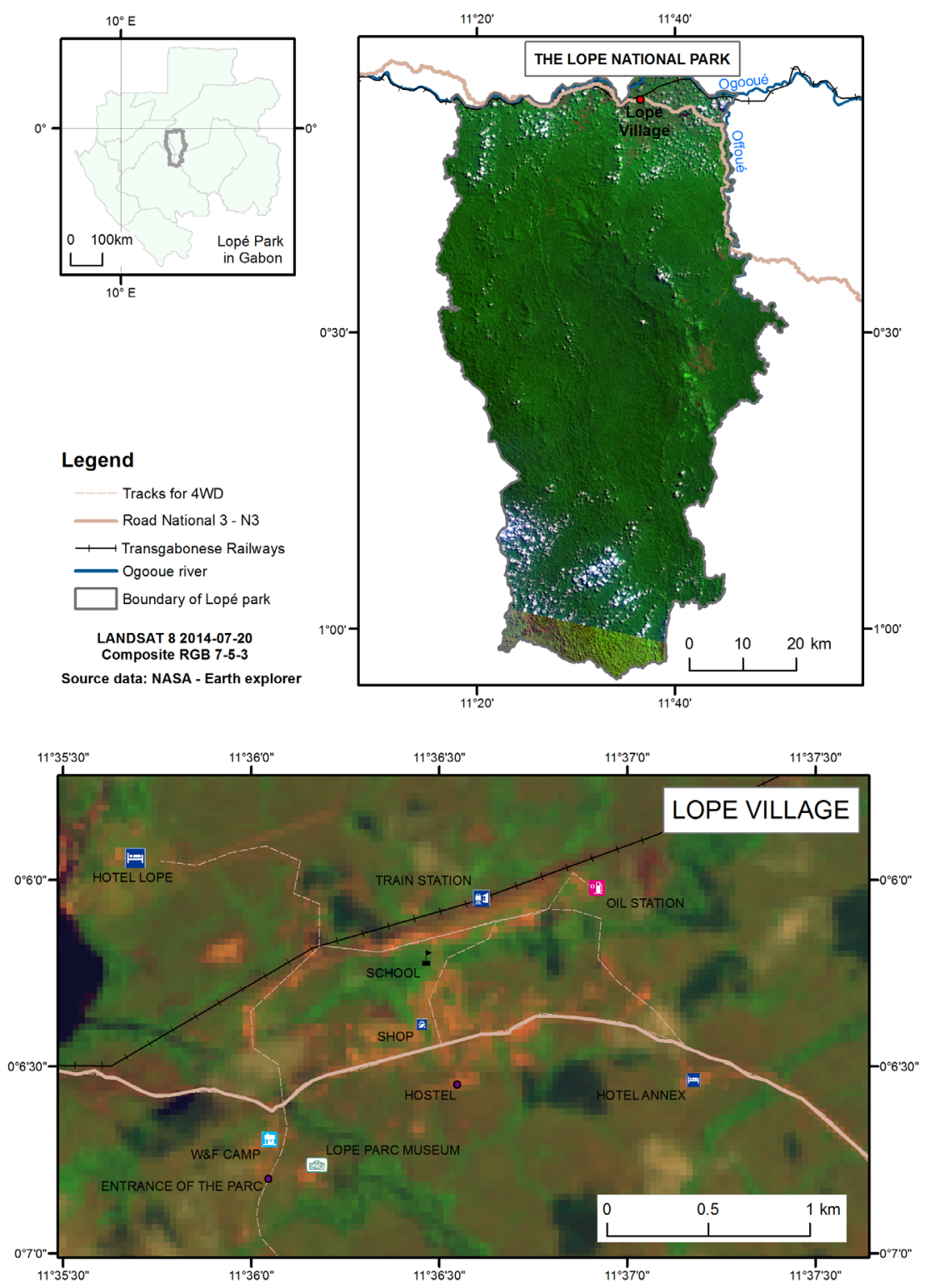

The area is characterized by a significant ethnic and linguistic mosaic. There are four language families, including an endemically disappearing Okandé group. The remaining dominant ethnic groups include Simba and Saké, and Babongo Pygmies in the south.

The area of the current park became a protected area a fauna reserve in 1946. However, protection was not efficient. In 1962 it was turned into a "rational" flora management zone, and in May 1996 a strict reserve (intégrale) was created on more than 167000 ha and enlarged several weeks later. The reserve was treated as a core of the future national park. Further 360000 ha were treated as a peripheral zone in which business activities, especially forest management, was subject to strict regulations. In 2002 the area gained the status of a national park which was entered in 2007 on the list of the UNESCO World Heritage Sites.

This area is one of the oldest protected areas in the country and simultaneously one of the most frequently visited by tourists.
Their number is however very small, especially in comparison with other African national parks, e.g. in eastern and southern Africa. Significant differences are noticeable also in the manner and efficiency of management of this area, which should involve shaping an in situ nature protection function and sustainable ecotourism.

The current situation in the La Lopé National Park was analyzed according to SWOT, which involved segregation of data into four categories of strategic factors: Strengths, Weaknesses, Opportunities and Threats. In this assignment, alike the majority of similar analysis, it was assumed that strengths and weaknesses are identical to the internal factors, while opportunities and threats belong to the external environment.

\section{Strengths}

The most significant strengths of the analyzed area include nature, which is an exception in the global scale and 
relatively little transformed as a result of human activities. A dominant landscape form is a park savannah mosaic (its age is estimated to be 40000 years) and a rain forest, which grows on the area since the Pleistocene, typical for neighboring hills of the Chaillu Massif. Along the rivers there are gallery forests. In the northern part of the park the forest is thinner, there are also many fragments of the secondary forest with marantaceae plants and a young forest. They constitute habitats favorable for large mammals. It is estimated that thanks to this the mammal biomass in this area is one of the largest currently recognized in the tropical rain forests (Ango 2008, p. 20). The population density of gorillas, chimpanzees and forest elephants is the highest in Africa. Probably the last male lion was shot in the Lopé savanna in 1969 (Henschell 2006).

Fauna and flora biodiversity is significant, however not completely recognized. Previously (2006) detailed research was conducted only in $1 / 4$ of the park area. The south-west part is nearly unrecognized botanically and it is claimed to be potentially the richest. 1500 species of plants (belonging to 700 types and more than 120 families) were identified, out of which the Rubiaceae family is the richest. The most endemically valuable species include Cola lizae, Dialium lopense and Begonia lopense. Subsequent research missions resulted in discoveries of previously unknown species, such as Engomegoma from the Olacaceae family described in 1996 (Breteler et al. 1996). Biodiversity is especially noticeable in the transition zone between the forest and the savannah, in which there are secondary forests of various age.

The most well-known species of animals in the La Lopé park include primate monkeys (10 daytime species and 6 nocturnal), forest elephants (Loxondonta cyclotis) and buffalos (Syncerus caffer nanus). Four species of primate monkeys: Cercopithecus solatus - endemic, Colobus satanas - population estimated at approx. 100 000, but rare in other parts of Africa, Pan troglodytes, Gorilla g. gorilla (especially threatened with extinction), belong to the group of animals which are very endangered in Africa (Oates 1996). The population of western lowland gorillas is estimated at 2000-3000, and chimpanzees - at more than 2000. This makes the La Lopé National Park one of the most important in situ protection places of these species in Africa. The park is also a significant place for the protection of mandrills (Mandrillus sphinx), the biggest nonhuman primates. $70 \%$ of their global population is in Gabon. Density of the primates is estimated at 20 specimen per $1 \mathrm{~km}^{2}$, and the size of herds - between 600 and 800 (Plan de gestion, 2006, p. 15), or even 1300 specimen (Ndémanou b.d). Also 17 species of cloven-hoofed animals and 13 species of predators were observed.

The park is also characterized by significant ornithological diversity (in 1997 - 369 species per 675 recognized in Gabon).

The natural strengths are accompanied by cultural strengths, as well. First traces of human presence in the area of the current park date back to Lower Palaeolithic Age -400 thousand years BC (Oslisly, Peyrot 1993). Artefacts from the Neolithic Age and later eras were preserved. The most important artefacts include engravings and rock drawings (more than 2000 in several location of the park and its peripheries) and stone tools (also from the lower and middle stone age) on the outskirts of the Park, especially numerous along the valley of the central Ogooué. Archeological traces indicate constant human presence in the area and allow us to follow technological evolution there (among others: traces of iron smelting). Thanks to their specific location they were not destroyed in the times of Christianization and colonization.

The La Lopé National Park is one of the oldest archaeological sites in Africa. The total surface area of the site with historical significance is $207 \mathrm{~km}^{2}$ (Ndémanou b.d.). In 2007 these sites were entered on the list of the UNESCO World Heritage as the first

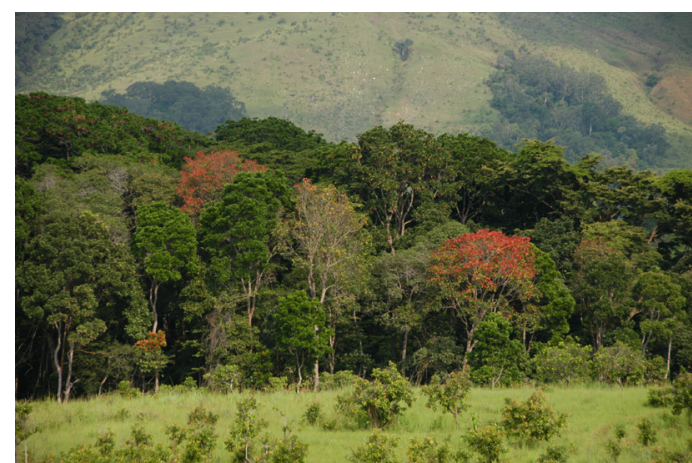

Figure 1. Landscapes of Lopé National Park. photo: M. Jędrusik

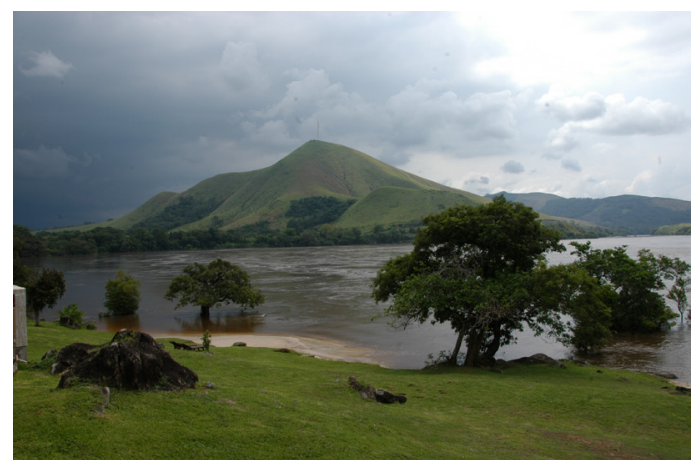

Figure 2. Landscapes of Lopé National Park. photo: M. Jędrusik

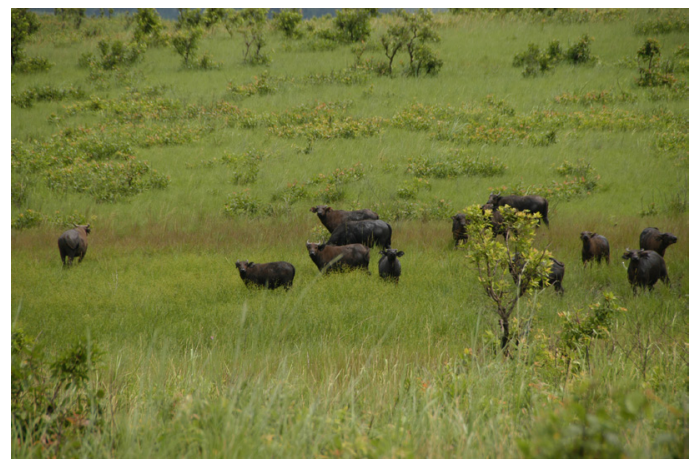

Figure 3. Buffalos (Syncerus caffer nanus) in Lopé NP. photo: M. Jędrusik

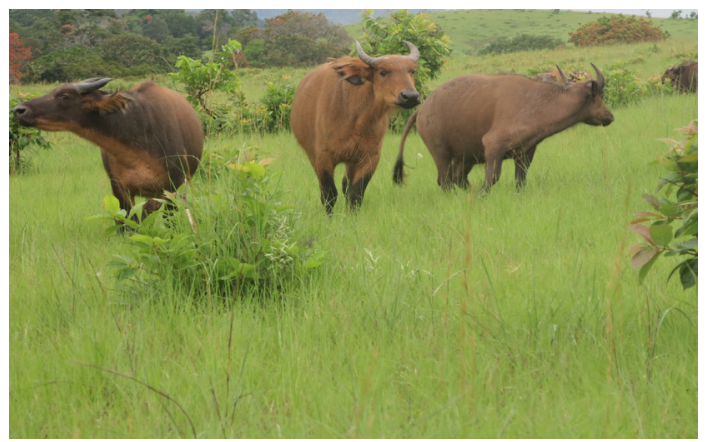

Figure 4. Buffalos (Syncerus caffer nanus) in Lopé NP. photo: A. Lisowski

ones in Africa under the name: Ecosystème et paysage culturel relique de la Lopé-Okanda. This obliges national authorities to act, but no actions have been seen. 


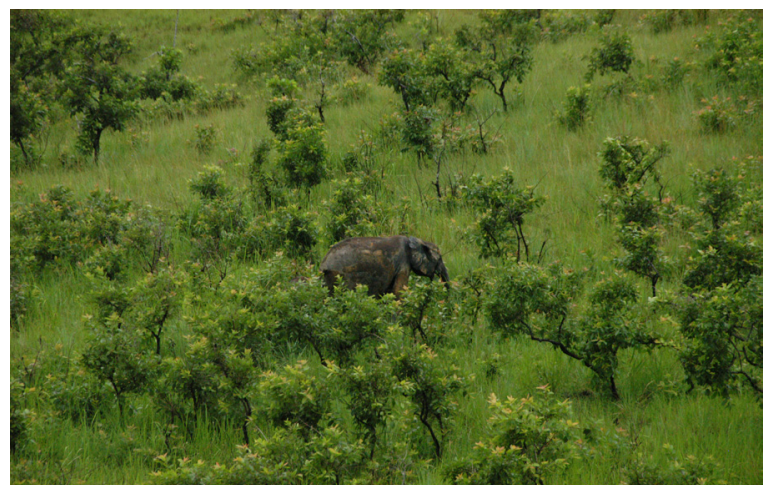

Figure 5. Forest elephant (Loxondonta cyclotis) in Lopé NP. photo: M. Jędrusik

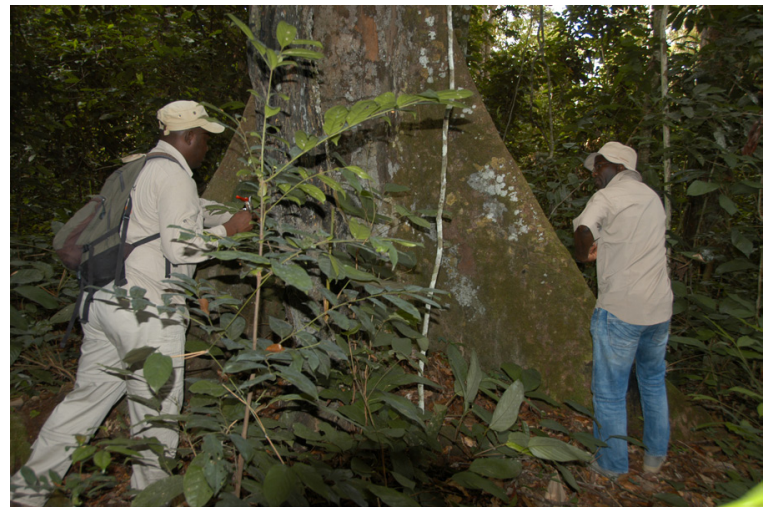

Figure 6. Two rangers in Lopé NP. photo: M. Jędrusik

\section{Weaknesses}

The weakest elements in the La Lopé National Park and the contiguous zone include an imperfect technical, social and touristic infrastructure, as well as deficiencies in the organization of the functionality of the park.

The touristic infrastructure on the site was monopolized by the safari operator from "Lopé Hotel". Tourists include mainly foreign residents of Gabon working in Libreville or Port Gentil (oil exploitation). Residents of Gabon do not come as the touristic services are too expensive.

The largest hotel - "La Lopé Hotel", which was established in 1992, has 18 bungalows with 30 rooms of various standards (four types). They have two conference rooms for 100 and 1520 people. Rooms are air-conditioned, equipped with cable television and bathrooms with warm water. Periodically electricity is turned off which makes it impossible to use the installations. The best rooms have terraces and hammocks. Prices depend on the standard and in December 2014 they oscillated between CFA 52000 and CFA 95500 (from EUR 80 to 145). Meals are not included. Breakfast (French) is CFA 7500 (EUR 12), and dinner - CFA 19000 (EUR 30). The touristic offer includes five types of trips - trekking in the forest, safari in a four-wheel drive car (the hotel has one such car), climbing Mont Brazza, sightseeing a modest eco-museum and a trip by motorized canoes or by car to archeological sites. The cost of a half-day trip is 20000 , and a whole-day trip - CFA 30000 (EUR 3045).

The hotel is nicely situated above the Ogooué river bend, however it is rarely visited. The number of visitors is hard to determine. At the beginning of December 2014 only one (!) room was taken. A local tour guide estimated the annual number of visitors at approximately several hundred of people. Entries on the Tripadvisor portal suggest that in 2012 the hotel was visited

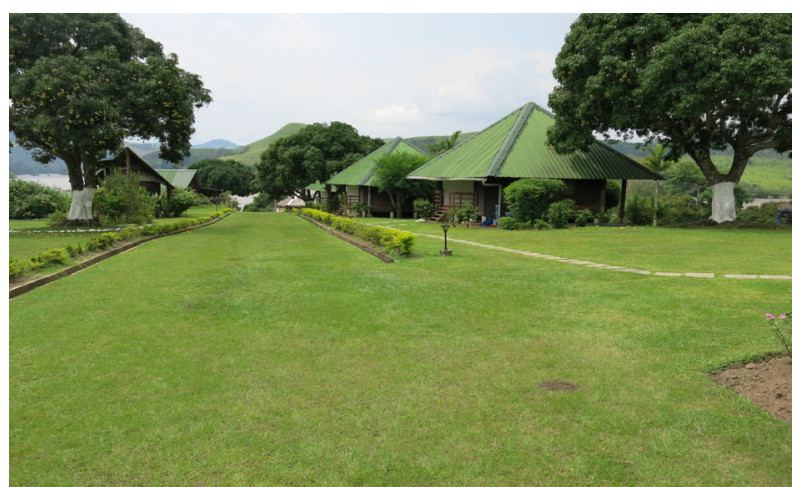

Figure 7. Luxurious Lopé Hotel. photo: M. Jędrusik

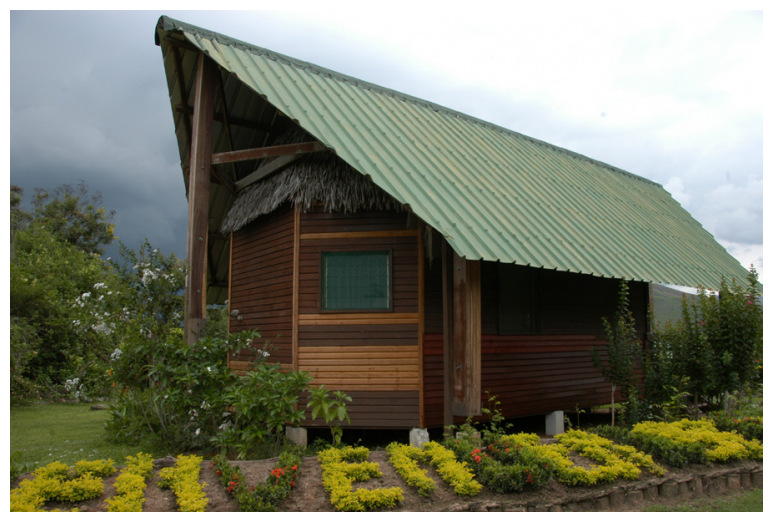

Figure 8. Luxurious Lopé Hotel. photo: M. Jędrusik

by approx. 2000 people. However, the number seems to be overestimated. What is interesting is the fact that between 2011 and 2014 only 12 opinions were entered. Almost all of them contained a lot of negative feedback, e.g.: the private cabins are suffering from a lack of maintenance. Among eight cabins used by our group, some were without hot water, others had wiring but missing lights. The staff will smile and promise to attend to problems, but nothing was repaired over four nights. Or: They could do much butter, but they don't. Take it or leave it but then to what? Enormous place, many rooms, but it definitely lacks the charm you'll find in eastern Africa. (Tripadvisor. Lope Hotel 2015)

Moreover in Lopé there is a small motel (Embeyi, Annex Lopé Hotel) - with 11 twin rooms in two pavilions - which constitute an annex to the main hotel. Its advantage is a lower price (CFA 25000 / EUR 40) and the fact that it is located closer to the center of the town. The standard of the rooms is very low.

In the town, you can also find accommodation in very Spartan conditions in a pension Chez Papa Jules (several rooms for CFA 5000-10000 / EUR 715) which was established in the season of 19951996. The rooms in both pensions are not secured with mosquito nets which significantly decreases the health safety of the guests (high risk of malaria; large numbers of tsetse flies). Local tourists can also stay in 34 very simple local motels next to the railway station.

Since 2001 there has also been a small Mikongo camp (Mikongo Lodge) near the north-east border of the park, close to the road to Franceville, with six bungalows for 12 people. The camp was established as a research station to study the life of gorillas, and the income from tourism was supposed to partially provide funds for the research. However, the only opinion (!) entered on the Tripadvisor portal of people who stayed there in 2011 is not too encouraging: Today Camp Mikongo is simply 


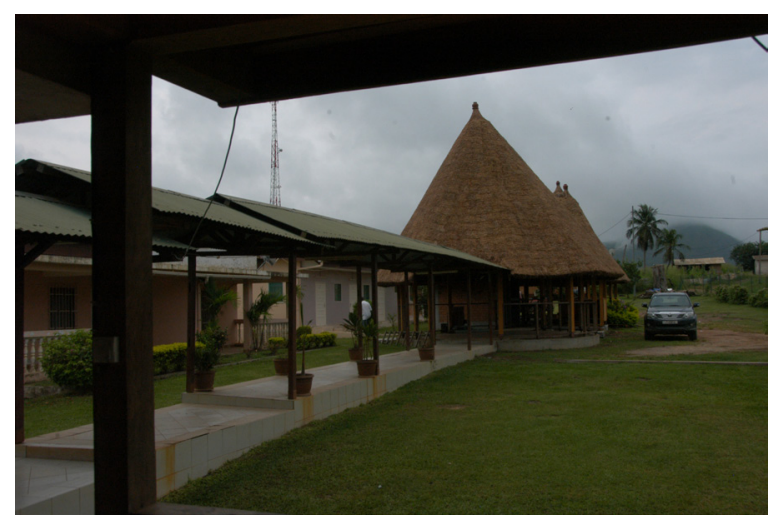

Figure 9. Motel in Lopé. photo: M. Jędrusik

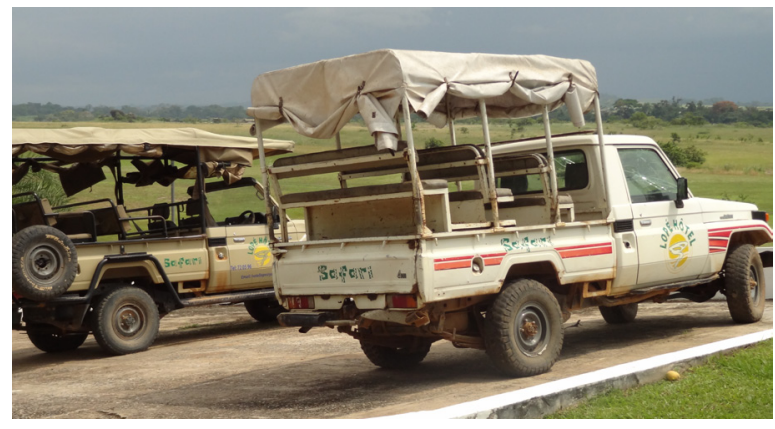

Figure 10. All-road vehicles used for trips in the Park. photo: M. Jędrusik

abandoned and we spent a night there like clandestines, being the only guests (Tripadvisor. Mikongo Forest Lodge 2015) In the Ololo camp, situated further to the south, trips by boats along the Offoué river were organized after the establishment of the national park. Their purpose was to observe elephants, crocodiles, gorillas and birds, but many participants of the trips were disappointed as the animals frequently turned out to be masters of camouflage.

As you can assume from the description above, the accommodation base is very modest. Prices are high and personnel is not too competent. Value for money is unfavorable in comparison with other areas in Africa with similar offers. One of the reasons is the lack of competing investors on the site. It is however difficult to invest when the touristic traffic is so low. It is not easy to determine what the cause and what the effect is.

Catering services are equally imperfect. The largest and the most expensive restaurant is in "Lopé Hotel" and its menu lacks diversity. A simple meal can be ordered in "Embeyi". Moreover, 5 simple restaurants can be found in Lopé ( $L a$ Mar d'Or is the best one), but their standard is difficult to accept for tourists from Europe. Two of them are located close to the railway station.

There are no banks, ATMs or exchange points in the town. Transactions using credit cards are possible only in the largest hotel, and judging by the entries of tourists - only sometimes. There are no petrol stations. There is a primary school and a vocational school with extended curriculum in forestry and tour guiding. Electricity is supplied by a small power plant situated near the railway station (diesel is the raw material). There are a few small shops.

The weakness of the touristic functionality of the area is intensified by the lack of qualified personnel to handle the touristic traffic. It concerns hotel services and guiding services (van de Weghe 2007). Possibilities to observe gorillas, mandrills and

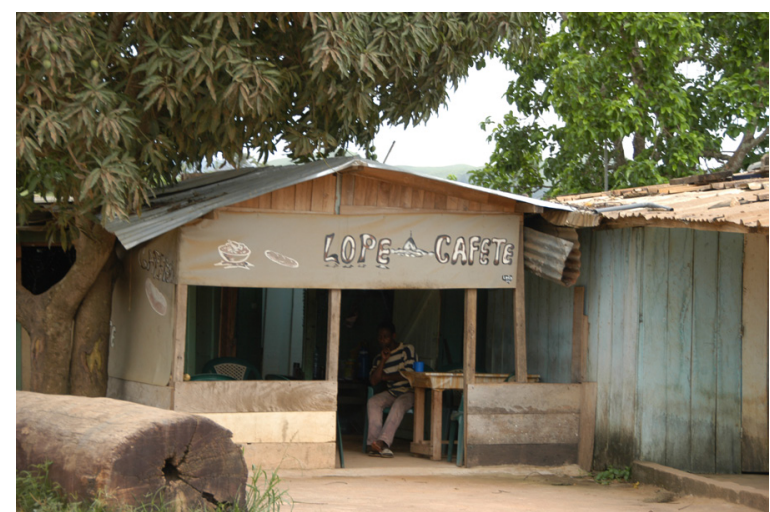

Figure 11. Shops and restaurants in Lopé village. photo: M. Jędrusik

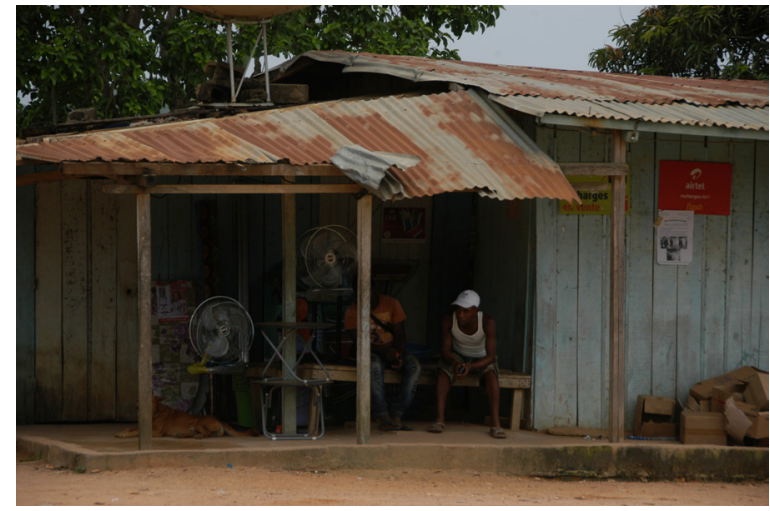

Figure 12. Shops and restaurants in Lopé village. photo: A. Lisowski

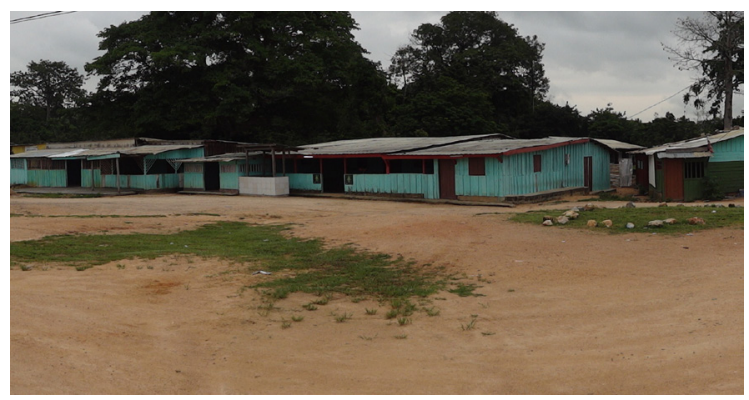

Figure 13. Shops and restaurants in Lopé village. photo: B. Zagajewski

birds by tourists are more limited than in other national parks of central Africa. One should remember about poor equipment with telemetry measures and low qualifications of employees responsible for the park. During an observatory mission in 2014 we managed to see forest elephant herds and buffalo herds, as well as arboreal monkeys (colobinae), which was a result of the guide's competencies. Generally the quality of services is poor. An entry of one of the tourists on Tripadvisor shows the scale of this problem: Deux guides nous donnent des explications totalement contradictoires à propos des gravures rupestres qu'ils nous font visiter (il y en a donc au moins un qui raconte n'importe quoi) ${ }^{2}$ http://www.tripadvisor.com/Hotel_Review...

2 "Two tour guides provided extremely different interpretations of engravings which were shown to us (so at least one of them was talking crap)". 
The analyzed area presents itself poorly regarding education, ecology (a small museum in the main headquarters of the park) and administration. The park functions poorly and ineffectively. Conflicts with other organizations operating in La Lopé repeat themselves: Wildlife Conservation Society, Station d'Etudes des Gorilles et Chimpanzes (SEGC), Zoological Society of London.

Borders of the residential estates in the neighboring zone are not designated administratively which intensifies conflicts between humans and nature. There are attacks of wild animals (including elephants) which destroy village infrastructure. Losses are not being compensated for, which intensifies the reluctance of people towards the idea and the personnel of the park.

Reluctance towards the authorities of the park results from the lack of investments in social infrastructure on the outskirts of the park and the lack of monitoring of illegal felling. Because local people are not offered to work for the park, they are not motivated to take care of the local natural resources. It is interesting that tour guides in the park are also poorly motivated financially, as they do not participate in the profit from guiding tourists.

In the park illegal felling and poaching happen on daily basis. The personnel of the park is rather limited. Richard Ndémanou mentions that in the park 11 rangers $^{3}$ are employed, including two women - one is pregnant and another one is on maternal leave. The rangers supervise savannahs more than forests. The south is especially deprived of control. It favors illegal felling. Near the Lopé residential estate there is an entering gate to the park, where theoretically the rangers can control the vehicles leaving the protected areas in La Lopé. However, there is no shed in this control point. During frequent rainfalls rangers leave the place, which makes illegal transport of trees and animals easy. Rangers' patrols consist of 3-4 people. Two of them have a guard between 8:00 am and 1:00 pm and 1:00 pm and 6:00 pm. Therefore, at night the park border is not guarded. During our observatory mission in December 2014 the checkpoint was also empty during the day. Wood, animal meat (viande de brousse) and ivory are taken out of the park. R. Ndémanou writes as follows: „lack of transparency in commercial hunting rules in La Lopé does not allow us to objectively estimate the number of animals killed by poachers, but it is certainly significant". Moreover, the number of patrols and other repressive activities against poachers is decreasing, which intensifies the illegal procedure.

Additionally damages in flora are caused by a railway line going through the park. Accidents involving animals are frequent. The railway between Libreville and Franceville favors poaching and export of contraband from the park. The logs of valuable species of trees ready for export and gathered by licensed entrepreneurs, placed near the railway station constitute a surprising view for a visitor of the national park.

Richard Ndemanou pays attention to nepotism - family relationships between the Chief Conservator of the park and one of the rangers responsible for controlling the income from the fees for entering the park. This favors abuse and the lack of control over profits. In general the prices of entry to the park are contractual and they are not controlled.

\section{Opportunities}

Rational development required a lot of good management and demand for the presented offer. In the case of the La Lopé National Park demand is expressed as the presence or the lack of tourists.

From 1992 to 2001 the La Lopé National Park was visited by 1000 tourists (Ndémanou n.d.). Later their number significantly increased - in absolute numbers. S. Ango (2008; Monaghan S 2007,

${ }^{3}$ Status as of the second half of the first decade of $21^{\text {st }}$ century. „Fiche signalétique...” published on-line in 2012 provides the personnel status as 8 positions: conservator, 5 rangers, 1 director's assistant, 1 technician.

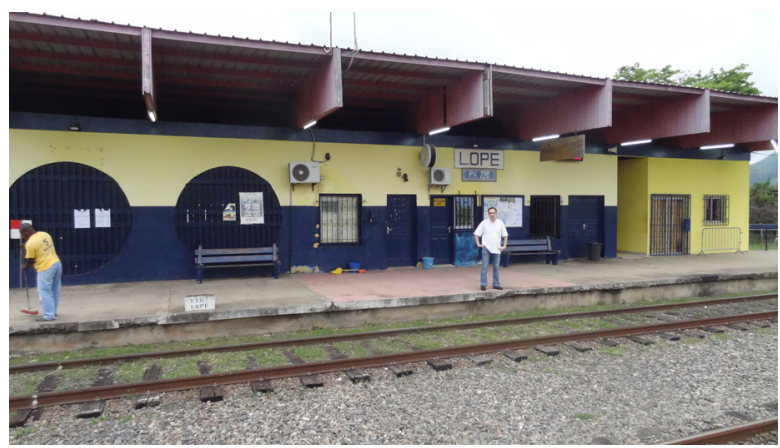

Figure 14. Lopé railway station. photo: B. Zagajewski

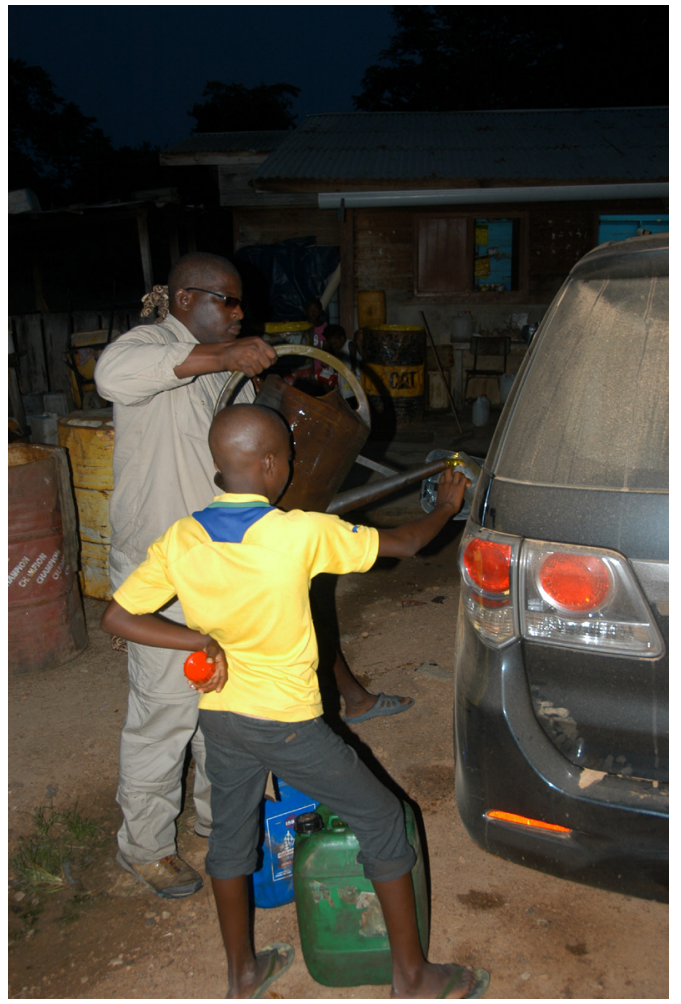

Figure 15. Unofficial petrol station in Lopé. photo: M. Jędrusik

p. 33) writes that the La Lopé National Park in 2006-2007 was visited by approximately 2000 tourists annually. In December 2014 during our observatory mission it was estimated that in 2014 eight hundred people visited the park, but all the estimates were burdened with inherent uncertainty, as the official registration leaves much to be desired. The most reliable estimates are related to the registration of the hotel guests in the most important hotel in the neighborhood "Lopé Hotel", but the employees of the hotel do not wish to make precise data available. It is worth remembering that the La Lopé National Park is the most popular of all national parks in Gabon.

Paradoxically, a small number of tourists can constitute an encouraging factor for others to visit this place - regarding the increasing fashion in the West to visit lesser travelled and transformed areas.

The La Lopé National Park is of particular interest for international organizations, especially scientific ones. It was mentioned before that the park was entered on the UNSECO World Heritage List (for its natural and cultural qualities). In 1983 
in the center of the strict protection area a research station to study gorillas and chimpanzees (Station d'Etudes des Gorilles et Chimpanzes - SEGC) was established. In the park also Wildlife Conservation Society and Zoological Society of London operate. Some projects are financed by SFish\&Wildlife service, Missouri Botanic Garden, WWF and EU. The park belongs to RAPAC (Réseau des Aires Protégées d'Afrique Centrale, Fiche signalétique...). As mentioned before, conflicts with the park administration occur from time to time and they often result from a different idea of nature protection. The presence of such organizations favor the implementation of this idea.

\section{Threats}

The La Lopé National Park is hardly accessible for tourists. Foreigners do not come - as the costs of travelling to Gabon and staying there is very high - significantly higher than in similar African countries, especially in eastern Africa.

In the country, to get there from Libreville $(350 \mathrm{~km})$ you need all day, and the comfort of the journey is low. It is possible to travel by train (approx. 7 hours from Libreville, but the time table is not respected and the departure hours are not known) or by four-wheel drive car (7-9 hours, but a significant part of the road - even though it is marked as a national road - does not have hardened surface) $)^{4}$. Public transport by road practically does not exist. The cost of travelling by light aircraft to the airstrip at the Lopé hotel is very high and only few people can afford to travel in such a manner.

Internal threats also include constant pressure on the environment: the pressure is expressed by hunting and poaching, fishing, felling, road construction, extraction of minerals, agriculture expansion, extraction of natural gas and crude oil, which favors fragmenting of dense forest complexes. Each drop of crude oil export is accompanied by an increase of the number of concessions for felling, also in protected areas. This increases threats for already endangered species and makes it difficult to effectively protect them. Felling is conducted to a large extent, frequently with the support and acceptance of the local population, also in the areas neighboring the park. Richard Ndémanou (n.d.) says that in Misseguelane (a Pygmies' village in the buffer zone of the park) an entrepreneur from Lebanon conducts forest felling using help of local people, who have work this way.

Ineffective and inconsistent ecological policy also constitutes an external threat. Although politicians and scientists undertake some initiatives, prepare analysis on the functioning of the National Park, the results of such initiatives remain on paper. In the first decade of the $21^{\text {st }}$ century a five-year plan (2006-2011) with very ambitious and rational assumptions was prepared for the park. Among others it was planned to develop ecotourism activities (novatrice). They were supposed to be compliant with the ecological and educational assumptions of the park, provide income which would allow to manage it and support the development of local societies. Management was supposed to favor local, national and international investments in tourism. In 2014 there are no results of its implementation. Perhaps it is even worse than in 2006.

Finally poor marketing and popularization of the La Lopé National Park abroad can be determined as a threat. Residents of western countries who are interested in ecotourism will find much more information about safaris in eastern Africa or national parks in southern Africa than about Gabon.

${ }^{4}$ Experiences in this field are various. Bruce Davidson $(2010-2011,8)$ has a different opinion: Serviced by tar road and a railway line it is possible to get to this national park with relative ease. (Rapac 2015)

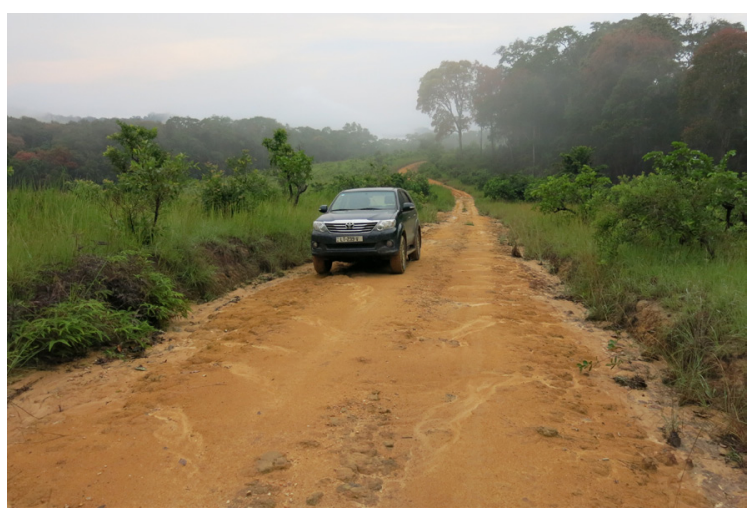

Figure 16. Roads in the national park. photo: A. Lisowski

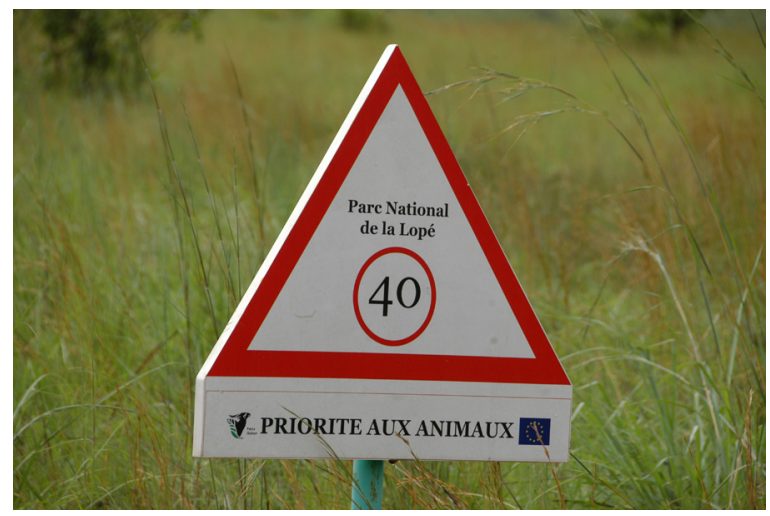

Figure 17. Examples of park-related information for tourists. photo: M. Jędrusik

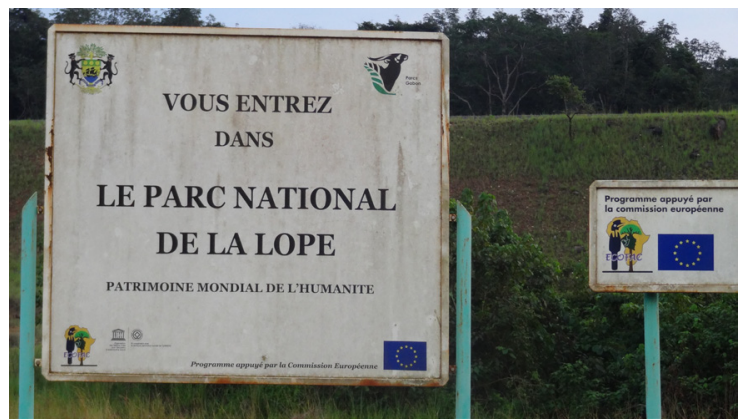

Figure 18. Examples of park-related information for tourists photo: A. Lisowski

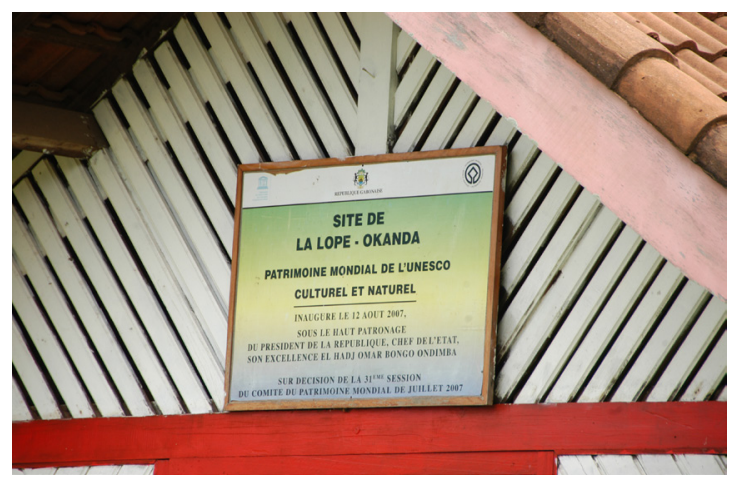

Figure 19. Examples of park-related information for tourists. photo: M. Jędrusik 


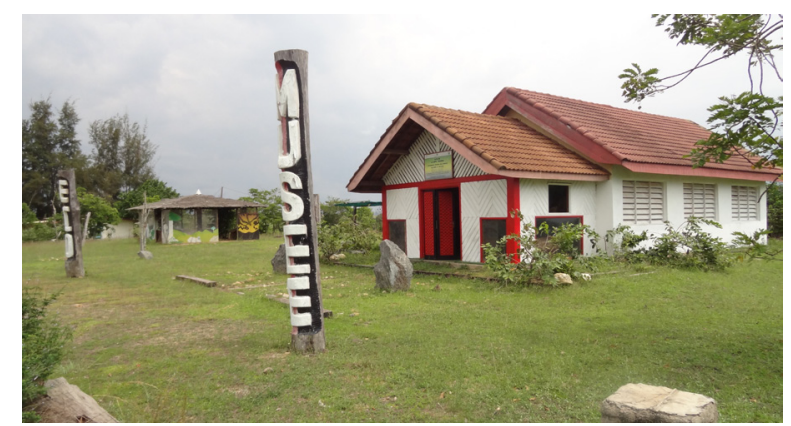

Figure 20. Examples of park-related information for tourists. photo: B. Zagajewski

\section{SWOT Analysis}

On the basis of the data presented above, we can assume that the most important SWOT features of the analyzed area include:

\section{S1 - unique landscape,}

S2 - significant biodiversity of fauna and flora,

$\mathrm{S} 2$ - presence of exceptional artworks,

S4 - small number of tourists,

W1 - very poor tourist management,

W2 - relatively high prices in relation to the quality offered,

W3 - conflicts between humans and nature (different kinds of nature),

W4 - conflicts between the interests of the local people and the functionality of the park,

W5 - risk of malaria and other diseases, throughout the entire country!

W6 - lack of transparency in funding and poor management of the park,

O1 - presence of international organizations and foreign scientists,

$\mathrm{O} 2$ - popularization of research results,

$\mathrm{O} 3$ - it is fashionable to visit "wild" parts of the world,

T1 - inconsistent environmental policy,

T2 - poaching and forest thinning,

T3 - high cost of travel to Gabon,

T4 - lack of good transport connections,

T5 - poor marketing.

Having determined the most important factors mentioned above, it is necessary to answer the following questions:

a) Will each of the strengths allow to take advantage of each opportunity?

b) Will each of the strengths allow to eliminate each threat?

c) Does each weakness limit possibilities to take advantage of each opportunity?

d) Does each weakness increase the risk related to each threat?

To obtain answers to these questions, the following matrix turns out to be useful, in which the numbers $0-2$ correspond to the lack of effect, poor effect or strong effect.

The quarter submatrix in which there are the strongest relations indicates the type of strategy which seems the most appropriate in order to achieve effective touristic development of the analyzed area.

\begin{tabular}{|c|c|c|c|c|c|c|c|c|c|}
\hline & 01 & O2 & O3 & & T1 & T2 & T3 & T4 & T5 \\
\hline S1 & 0 & 1 & 1 & S1 & 0 & 0 & 1 & 1 & 0 \\
\hline S2 & $\mathbf{2}$ & $\mathbf{2}$ & $\mathbf{2}$ & $\mathbf{S 2}$ & 0 & 0 & 1 & 1 & 1 \\
\hline S3 & $\mathbf{2}$ & $\mathbf{2}$ & 1 & $\mathbf{S 3}$ & 0 & 0 & 1 & 1 & 1 \\
\hline S4 & 1 & 0 & $\mathbf{2}$ & $\mathbf{S 4}$ & 0 & 0 & 0 & 0 & 0 \\
\hline W1 & 0 & 0 & 1 & $\mathbf{W 1}$ & 0 & 1 & 0 & 0 & $\mathbf{2}$ \\
\hline W2 & 0 & 0 & 1 & $\mathbf{W} 2$ & 0 & 0 & $\mathbf{2}$ & $\mathbf{2}$ & 1 \\
\hline W3 & 0 & 0 & 0 & $\mathbf{W 3}$ & 1 & $\mathbf{2}$ & 0 & 1 & 0 \\
\hline W4 & 1 & 0 & 1 & $\mathbf{W} 4$ & $\mathbf{2}$ & $\mathbf{2}$ & 0 & 0 & 0 \\
\hline W5 & 1 & 0 & 1 & $\mathbf{W 5}$ & 0 & 0 & 1 & 0 & 0 \\
\hline W6 & 1 & 1 & 0 & $\mathbf{W 6}$ & $\mathbf{2}$ & $\mathbf{2}$ & 0 & 1 & 1 \\
\hline
\end{tabular}

From the analysis it can be concluded that a conservative strategy and a competitive strategy would be the most ineffective, as they correspond to the second and third quarter in the matrix.

Numerous strong relations are indicated by the fourth quarter which could favor a defensive strategy. In this case weaknesses of the park are strongly related to external threats. These threats intensify the effects of weaknesses of the park. External pressure can lead the park to ruin and deprive it of its possibilities to implement basic purposes (i.e. for example to the lack of tourists and benefits of ecotourism or to a significant decrease of valuable natural resources). The defensive strategy can only help the park survive, but it is difficult to assume that it will favor touristic development of the area.

Therefore, the most appropriate strategy seems to be an aggressive strategy. Strengths in a strong relation with opportunities can constitute a basis to increase the significance of the park, as well as the material (income from tourism), and non-material benefits (more efficient nature protection).

\section{Conclusions}

As it is seen in the above analysis, the La Lopé National Park was treated as an enterprise, as it actually is such an entity. It is directly and indirectly managed by the national authorities, the task of which is corporate governance, as well as selection and consistent implementation of the development strategy.

Previous activities in this field are ineffective, as mentioned before. Reasonable Plan de gestion du Parc National de la Lopé 2006-2011 which took into account the potential, as well as ecological and cultural limitations of the park, remained on paper.

Observations and comparisons of the current situation with the records of the plan indicate that there was a significant regress of the park development regarding management, nature protection and sustainable development in the last decade.

The lack of efficient protection of natural resources, the lack of investments in infrastructure, the lack of mediation with the residents of the area, and the lack of their involvement in proecological (e.g. in ecotourism) activities constitute threats to the foundations of the existence of the park. If the authorities of Gabon do not wish the area to be a destination of journeys for those, who would consciously like to experience inconvenience, discomfort and uncertainty, it is important that people responsible for the key decisions realize that.

And it might be the most important conclusion of this article. What is the purpose of multiplying and repeating recommendations which have been developed and made public before. 


\section{Acknowledgments}

The observatory mission in the La Lopé National Park was financed by University of Warsaw and Université Omar Bongo in Libreville within the framework of a cooperation agreement between these institutions concluded in 2014.

References

Ango, S 2008, La valorisation des Parcs Nationaux et les politiques de coopération culturelle et scientifique, Ecole Nationale d'Administration, Libreville.

Breteler, FJ, Baas, P, Boesewinkel, FD, Bouman, F \& LobreauCallen, D 1996, 'Engomegoma gordonii (Olacaceae) a new monotypic genus from Gabon', Botanische Jahrbücher, vol. 118, pp. 113-132.

Henschel, P 2006, 'The lion in Gabon: historical records and notes on current status'. CAT News, vol. 44, pp. 10-13.

Fiche signalétique RAPAC Parc National de la Lopé, 2015. Available from: <http://www.rapac.org/index. php?option $=$ com_docman\&view $=$ download\&alias $=241$ parc-national-de-la-lope\&category_slug=fichessignaletiques-aires-protegees \&Itemid=100206 > . [12.02.2015].

Monaghan, S 2007, Consécration méritée. Available from: <http://www.gabonmagazine.com/images/G9-FRENCH/ GABON9.lope.french.pp30-33.pdf>. [10.02.2015].

Ndemanou, R n.d., La problématique de gestion des aires protégées en Afrique Centrale : le cas du parc national de la Lopé-Okanda au Gabon. Available from: <http:// www.sifee.org/static/uploaded/Files/ressources/actes-descolloques/yaounde/session-4-3/3_NDEMANOU_TXT.pdf>. [11.02.2015]

Oates, JF 1996, African Primates: Status Survey and Conservation Action Plan. Gland. IUCN.
Oslisly, R \& Peyrot, B 1993, Les gravures rupestres de la vallée de l'Ogooué (Gabon). ed. Sépia, Paris.

Plan de gestion du Parc National de la Lopé 2006-2011, 2006, CNPN, Libreville

Rapac, 2015. Available from : <http://www.rapac.org/ index.php?option=com_docman\&view=document\&la yout $=$ default $\&$ alias $=17 \overline{4}-$ Photographic-and - TourismPotential-Report-on-8-RAPAC-pilot-sites-located-in-8central-african-countr\&category_slug=developpementtouristique\&ltemid=100206>. [16.02.2015].

Tripadvisor. Lope Hotel, 2015. Available from: <http://www. tripadvisor.com/Hotel_Review-g488097-d2230073Reviews-Lope_Hotel-Lope_Wildlife_Reserve_Ogooue_ Ivindo_Province.html\#REVIEWS>. [12.02.2015].

Tripadvisor. Mikongo Forest Lodge, 2015. Available from:<http:// pl.tripadvisor.com/Hotel_Review-g488097-d480644Reviews-Mikongo_Forest_Lodge-Lope_Wildlife_Reserve_ Ogooue_Ivindo_Province.html>. [13.02.2015].

van de Weghe, JP 2007, Loango Mayumba et le Bas-Ogooué: eaux noires, forêts vierges et baïs, Wildlife Conservation Society, Libreville.

White, LJT \& Abernethy, KA 1996, Guide de la végétation de la Réserve de la Lopé, Gabon. Ecofac-Gabon, CIRMF, USAAID. 